\title{
PENINGKATAN KOMPETENSI PROFESIONAL GURU MELALUI WEBINAR EVALUASI HASIL BELAJAR BAGI GURU-GURU MTs. AL-MA'ARIF 1 AIMAS
}

\author{
Wini Tarmini ${ }^{1}$, Imam Safi' $i^{1}$, Yeni Witdianti ${ }^{1}$, Suci Larassaty ${ }^{1}$ \\ ${ }^{1}$ Universitas Muhammadiyah Prof. DR. HAMKA, Jakarta, Indonesia \\ imamsafii2077@uhamka.ac.id
}

\begin{abstract}
Abstrak: Penyusunan instrumen evaluasi hasil belajar dan pelaksanaannya secara daring merupakan salah satu kompetensi profesional yang harus dimiliki oleh guru saat ini. Sebagian besar Guru MTs. Al-Ma'arif 1 Aimas belum terampil dalam memanfaatkan media daring sebagai media penyusunan dan pelaksanaan evaluasi hasil belajar. Kegiatan pelatihan ini bertujuan untuk meningkatkan kompetensi para Guru MTs. Al-Ma'arif 1 Aimas, Sorong dalam menyusun instrumen evaluasi hasil belajar secara daring dengan menggunakan media Quizizz. Metode yang digunakan dalam upaya peningkatan kompetensi para guru adalah melalui kegiatan pelatihan. Tahapan yang digunakan dalam pelatihan ini adalah tahap eksplorasi, elaborasi, dan konfirmasi. Tahap eksplorasi diawali dengan pengajuan beberapa pertanyaan melalui Google Form yang berkaitan dengan pemahaman para peserta pelatihan tentang evaluasi dan berbagai media yang dapat digunakan untuk melalukan evaluasi hasil belajar. Tahap elaborasi adalah berupa penjelasan dan pelatihan penyusunan instrumen evaluasi hasil belajarn dengan menggunakan media. Pada tahap konfirmasi para peserta pelatihan diminta untuk menyusun instrumen evaluasi, mengatur waktu pengerjaan, membagikan link dan kode room kepada siswa, dan menganalisis hasil belajar dengan menggunakan penggunaan media Quizizz. Hasil kegiatan menunjukkan bahwa pemahaman dan kompetensi para Guru MTs. Al Ma'arif 1 Aimas Sorong meningkat secara signifikan, yaitu dengan rata-rata awal $25,9 \%$ menjadi $86,6 \%$. Kegiatan pelatihan ini dapat dijadikan salah satu model pelatihan untuk meningkatkan kompetensi profesional para guru.
\end{abstract}

Kata Kunci: pelatihan, evaluasi hasil belajar, Quizizz

\begin{abstract}
The preparation learning evaluation instruments and its online implementation are some of the professional competencies that must be possessed by teachers. Most of teachers in MTs Al-Ma'arif 1 Aimas are not yet skilled in utilizing online media as a medium for the preparation and evaluation of learning outcomes. This community service program aims to improve the teachers' competence to compile an instrument for evaluating learning outcomes online using Quizizz. The method used was training which consists of several stages: exploration, elaboration, and confirmation. The exploration phase began with the submission of a number of questions through the Google Form relating to trainees' understanding of the evaluation and various media that can be used to carry out evaluation of learning outcomes. The elaboration stage was in the form of explanations and training in the preparation of evaluation instruments for learning outcomes using Quizizz. At the confirmation stage, the trainees were asked to compile an evaluation instrument, arrange working time, share links and room codes with students, and analyze learning outcomes using Quizizz. The results show that the teachers' understanding and competence in MTs Al Ma'arif 1 Aimas Sorong have increased significantly, with an initial average of $25.9 \%$ to $86.6 \%$. This training can be used as an alternative model of training to improve the professional competence of teachers.
\end{abstract}

Keywords: training, evaluation of learning outcomes, Quizizz

\section{Pendahuluan}

Pelaksanaan dan penyusunan instrumen evaluasi hasil belajar yang baik dapat menjadi salah satu indikator kompetensi profesional dari guru (Safi'i \& Amar, 2019). Evaluasi hasil belajar menjadi pilar utama dalam proses pembelajaran tepatnya di dunia pendidikan, baik bagi guru 
maupun peserta didik (Mastuti, 2016). Melalui evaluasi, akan diperoleh gambaran mengenai tingkat keberhasilan proses pembelajaran yang telah dilaksanakan. Hasil evaluasi merupakan informasi yang berharga bagi individu untuk mengambil keputusan berkaitan dengan pendidikan dan latihan yang telah ditempuhnya (Purnomo, 2005). Evaluasi hasil belajar juga dapat dijadikan sebagai salah satu tolok ukur keberhasilan dalam pendidikan sekaligus dapat dijadikan sebagai landasan untuk meningkatkan kinerja atau prestasi peserta didik, guru, dan institusi atau lembaga pendidikan itu sendiri. Oleh karena itu setiap guru harus mampu mengembangkan instrumen evaluasi dengan menggunakan berbagai media yang tepat.

Melihat urgensi evaluasi hasil belajar dalam dunia pendidikan tentunya memicu guru dan penyelenggara pendidikan untuk terus mengeksplorasi kualitas pengetahuannya yang terus berkembang seiring dengan perkembangan dan tuntutan zaman. Kaitan antara evaluasi belajar dan perkembangan zaman mengerucut pada penggunaan media. Hal ini membuktikan bahwa media memiliki peranan untuk meringankan atau mempermudah tugas seseorang yang dalam hal ini adalah guru. Misalnya, guru yang menguasai pemanfaatan media online atau daring dapat menyusun instrumen evaluasi hasil belajar secara lebih efektif. Di samping itu guru pun akan bisa secara cepat untuk mengetahui hasil evaluasi serta analisis dari butir soal yang telah disusunnya. Dengan demikian, guru pun akan lebih cepat dalam mengambil berbagai langkah tindak lanjut atas hasil belajar pembelajaran yang telah dicapainya.

Kemampuan penguasaan teknologi dalam menganalisis evaluasi hasil belajar siswa mutlak dalam menghadapi era revolusi 4.0. Terlebih lagi, hadirnya pandemi covid-19 (Corona Virus Disease) secara total telah mengubah pola pembelajaran, tidak terkecuali evaluasi hasil belajar. UNESCO menyebutkan, lebih dari 850 juta siswa di dunia tidak bisa belajar di sekolah akibat virus asal Wuhan, China tersebut (Rajab, 2020). Berkenaan dengan hal tersebut, maka pemerintah menetapkan Peraturan Pemerintah Republik Indonesia No. 21 Tahun 2020 Tentang Pembatasan Sosial Berskala Besar (PSBB) dalam rangka percepatan penanganan Coronavirus Disease 2019 (COVID-19). Merespon kebijakan tersebut para penyelenggara pendidikan yang dipandu oleh Kementerian Pendidikan diminta untuk menutup sekolah dan menerapkan pembelajaran jarak jauh. Penerapan pembelajaran jarak jauh atau daring tentu harus diimbangi dengan penggunaan media analisis hasil belajar e-learning (virtual) yang tepat dan efektif.

Media virtual merupakan merupakan media pembelajaran yang menggunakan perangkat lunak komputer yang berbasis web. Melalui media tersebut trainer dan peserta dapat melakukan interaksi di mana saja. Media virtual adalah salah satu alat paling efektif untuk melakukan pembelajaran atau pelatihan secara online (Kultawanich, Koraneekij, \& Na-Songkhla, 2015). Melalui media virtual tersebut, guru dan siswa dapat menjelajahi bidang yang diminati secara kolektif dan terorganisasi. Informasi yang diperoleh melalui kelas virtual dapat digunakan untuk perencanaan, kegiatan, penyelesaian masalah, dan penulisan esai (Crişan \& Enache, 2013).

Perkembangan media virtual berbasis web secara historis dalam beberapa dekade terakhir terus mengalami peningkatan (Morice, dkk., 2020). Dalam konteks ini, teknologi digital sering diajukan sebagai jawaban yang memungkinkan untuk mengubah lanskap pendidikan dan membuatnya lebih fleksibel serta mudah diakses untuk kelompok pelajar yang lebih besar (Raes, dkk., 2020). Media virtual juga merupakan strategi belajar mengajar maupun pelatihan yang 
efektif dan populer di kalangan pelajar karena mereka dapat berinteraksi secara bersamaan dalam audio atau teks, bahkan beberapa mahasiswa juga merasa lebih nyaman dalam mengekspresikan pendapat dalam kelas virtual (Daly, Rasmussen, \& Dalsgaard, 2019). Hal ini juga sejalan dengan hasil penelitian dari Cheng \& Tsai (2019), bahwa melalui media virtual motivasi para siswa pada umumnya mengalami peningkatan.

Salah satu media evaluasi berbasis e-learning (virtual) yang bisa diterapkan adalah aplikasi Quizizz. Aplikasi Quizizz memiliki beberapa keunggulan, yaitu efisiensi waktu dalam pengolahan hasil belajar, menghemat penggunaan kertas, menarik dan menyenangkan siswa, serta menyajikan data dan statistik tentang kinerja peserta didik. Hal ini sejalan dengan pendapat dari Purba (2019), bahwa Quizizz adalah sebuah aplikasi pendidikan berbasis game yang membawa aktivitas multipemain ke ruang kelas dan membuatnya di kelas latihan interaktif dan menyenangkan. Demikian halnya dengan pendapat dari Mei, Ju, \& Adam (2019), bahwa media Quizizzmenjadi salah satu alat evaluasi berbasis e-learning yang sangat efektif digunakan untuk mengevaluasi dengan cepat dan langsung memberi hasil kepada guru, sehingga dengan cepat dapat mengambil tindakan kepada siswa.

Selanjutnya yang menjadi pertanyaan adalah bagaimana kemapuan para guru di MTs. Al Ma'arif 1 Aimas Sorong yang juga terdampak Pembatasan Sosial Berskala Besar (PSBB) dalam melakukan kegiatan pengembangan instrumen valuasi hasil belajar secara virtual? Berdasarkan wawancara virtual yang dilakukan terhadap Kepala Sekolah MTs. Al Ma'arif 1 Aimas, Sorong diperoleh informasi, bahwa hampir semua guru di sekolah tersebut masih menggunakan media daring berupa e-mail dan WhatsApp, bahkan masih ada guru yang harus mendatangi satu-satu rumah peserta didik. Hal ini tentunya selain tidak efektif juga tidak sejalan dengan protokol PSBB yang memiliki tujuan untuk memutus mata rantai Coronavirus Disease 2019 (COVID-19) yang seharusnya segala sesuatu seharusnya di lakukan di rumah saja sebagaimana proses pembelajaran yang banyak dilakukan di kota-kota besar lainnya.

Bertolak dari permasalahan tersebut, maka melalui kegiatan pelatihan ini, kami melakukan kegiatan webinar melalui Google Meet berupa Pelatihan Evaluasi Hasil Belajar dengan Media Quizizz bagi Guru MTs. Al-Ma'arif 1 Aimas, di Kabupaten Sorong, Provinsi Papua Barat. MTs. Al-Ma'arif 1 Aimas, di Kabupaten Sorong, Provinsi Papua Barat merupakan salah satu sekolah swasta yang memiliki peserta didik cukup banyak. Pendidik atau guru di sekolah tersebut masih tergolong usia muda dan pada umumnya masih minim wawasan mengenai media pembelajaran daring. Kegiatan tersebut bertujuan untuk meningkatkan pemahaman dan kemampuan para guru dalam mengevaluasi hasil belajar siswa dengan menggunakan media online atau daring. Dengan demikian, dapat dijadikan sebagai salah satu upaya untuk meningkatkan pengetahuan dan kompetensi para guru dalam mengevaluasi hasil belajar siswa.

\section{Metode}

Pelatihan Evaluasi Hasil Belajar dengan Media Quizizz bagi Guru MTs. Al-Ma'arif 1 Aimas, di Kabupaten Sorong, Provinsi Papua Barat ini dilakukan dengan webinar melalui Google Meet. Peserta yang mengikuti pelatihan sebanyak 20 peserta. Metode yang digunakan dalam upaya 
peningkatan kompetensi para guru tersebut melalui pelatihan, yang dibagi menjadi tiga tahap, yaitu eksplorasi, elaborasi, dan konfirmasi.

Tahap eksplorasi adalah tahap awal yang dilakukan sebelum proses pelatihan dilaksanakan, yaitu upaya untuk mengetahui mengenai pemahaman serta kemampuan awal dari para peserta pelatihan tentang materi yang akan diajarkan. Kegiatan ekspolarasi juga bertujuan untuk meningkatkan fokus dan motivasi para peserta pelatihan. Hal ini selaras dengan pendapat Li, Wei, Zhao, \& Geng (2020), bahwa eksplorasi dalam kegiatan pembelajaran adalah sebuah pendekatan yang didorong oleh rasa ingin tahu. Kegiatan eksplorasi yang dilakukan adalah berupa wawancara virtual kepada mitra yang diwakili oleh kepala sekolah mengenai analisis kebutuhan atau persoalan yang dihadapi oleh mitra, urgensinya atas kegiatan pelatihan yang akan dilakukan terhadap mitra, serta pemahaman awal dari para peserta pelatihan terhadap media virtual Quizizz.

Tahap elaborasi pelaksanaan pelatihan, meliputi: a) penjelasan tentang media aplikasi Quizizz dan penggunaannya b) pemodelan tentang pemanfaatan media Quizizz dalam kegiatan evaluasi hasil belajar, c) memproduksi instrumen evaluasi hasil belajar dengan media Quizizz secara terbimbimbing, dan d) memproduksi instrumen evaluasi dengan menggunakan media Quizizz secara mandiri.

Tahap konfirmasi, pada tahap ini para peserta dievaluasi pemahaman serta kemampuannya dalam memproduksi instrumen evaluasi dengan menggunakan media Quizizz sesuai dengan mata pelajaran yang diampu oleh para peserta dalam melangsungkan pembelajaran di sekolah. Penilaian pemahaman para peserta tentang evaluasi serta media yang dapat digunakan dilakukan dengan tes yang diberikan melalui Google Form. Selanjutnya, Penilaian terhadap keterampilan atau kemampuan para peserta dalam memanfaatkan media Quizizz dilakukan melalui unjuk kerja atau praktik menyusun mengatur waktu pengerjaan, membagikan link dan kode room kepada siswa, serta menganalisis hasil belajar dengan menggunakan penggunaan media Quizizz. Berdasarkan hasil evaluasi tersebut, para peserta diberikan berbagai penguatan untuk meningkatkan pemahaman secara lebih lanjut tentang efektivitas pemanfataan media Quiizizz dalam melangsungkan kegiatan evaluasi hasil belajar secara online.

\section{Hasil dan Pembahasan}

Pada bagian ini akan dideskripsikan dua hal yang berkaitan dengan kegiatan pelatihan penyusunan instrumen evaluasi hasil hasil belajar dengan media Quizizz yang dilangsungkan secara online kepada para Guru MTs. Ma'arif Aimas Sorong, yaitu berupa proses pelatihan penyusunan instrumen evaluasi hasil belajar dengan menggunakan media Quizizz dan hasil pelatihan penyusunan instrumen evaluasi hasil belajar dengan menggunakan media Quizizz.

\section{Proses Pelatihan Penyusunan Instrumen Evaluasi Hasil Belajar dengan Mengguna- kan Media Quizizz}

Proses pelaksanaan pelatihan penyusunan instrumen evaluasi hasil belajar dilakukan melalui dua tahap, yaitu eksplorasi dan elaborasi. Pada sesi ekplorasi peserta pelatihan diberikan sejumlah pertanyaan melalui Google Form yang berkaitan dengan pengertian evaluasi, media 
evaluasi daring lainnya yang pernah digunakan dan pengetahuan awal tentang media Quizizz. Berdasarkan jawaban dari peserta pelatihan dapat diketahui bahwa pada umumnya peserta pelatihan telah melakukan evaluasi hasil belajar namun secara manual. Secara keseluruhan peserta pelatihan belum pernah menggunakan evaluasi hasil belajar daring lainnya ataupun dengan aplikasi Quizizz. Proses pembelajaran jarak jauh akibat terdampak coronavirus yang berlaku di sekolah mereka pun belum beragam. Media pembelajaran daring yang mereka gunakan baru sebatas surel dan WhatsApp.

Sebagaimana kita ketahui, bahwa dalam penyelenggaraan evaluasi pembelajaran ada dua pokok yang harus diperhatikan, yaitu pemahaman tentang evaluasi, dan pelaksanaan evaluasi. Pemahaman tentang evaluasi akan memungkinkan para guru dapat menyusun serta melaksanakan evaluasi dengan baik. Demikian halnya, pemahaman tentang beragam teknik evaluasi akan memungkinkan mampu secara tepat memilih dan mengembangkan beragam teknik yang tepat untuk melangsungkan evaluasi. Dengan demikian proses dan hasil evaluasi dapat berlangsung secara efektif serta dapat dipertanggungjawabkan hasilnya. Hal ini sangat relevan dengan apa yang diutarakan oleh Soffer, Kahan, \& Livne, (2017), bahwa mengevaluasi kualitas pembelajaran online sangat penting. Demikian halnya, memahami dalam menemukan manfaat dan penghalang juga sangat penting untuk menyesuaiakan pembelajaran yang sesuai dengan kebutuhan siswa. Dengan demikian semakin jelaslah, bahwa pemahaman guru tentang evaluasi serta media yang tepat dalam melangsungkan evaluasi memegang peranan yang sangat penting untuk mencapai tujuan pembelajaran.

Berikut ini hasil eksplorasi tentang pemahaman para peserta pelatihan terhadap evaluasi, media pelaksanaan evaluasi, dan media Quizizz dalam penyusunan instrumen evaluasi hasil belajar.

Tabel 1. Rata-Rata Pemahaman Awal Para Peserta Pelatihan tentang Evaluasi dan Pemanfaatan Media Online

\begin{tabular}{llll}
\hline $\begin{array}{l}\text { Pemahaman tentang } \\
\text { evaluasi }\end{array}$ & $\begin{array}{l}\text { Pemahaman tentang } \\
\text { media daring dalam } \\
\text { pelaksanaan evaluasi }\end{array}$ & $\begin{array}{l}\text { Pemahaman tentang } \\
\text { media Quizizz dalam } \\
\text { pelaksanaan evaluasi }\end{array}$ & Rata-rata \\
\hline $44,4 \%$ & $33,3 \%$ & $0,0 \%$ & $25,9 \%$ \\
\hline
\end{tabular}

Berdasarkan Tabel 1 di atas pemahaman awal para peserta pelatihan tentang evaluasi adalah adalah sebesar $44,4 \%$. Data tersebut menunjukkan, bahwa pemahaman para peserta pelatihan tentang berbagai hal yang berkaitan dengan prinsi-prinsip evaluasi belum maksimal. Evaluasi adalah bagian integral dalam pelaksanaan pembelajaran. Evaluasi atau penilaian dapat digunakan untuk mengetahui tingkat pemahaman serta kemampuan siswa terhadap materi yang telah dipelajarinya (Safi'i, 2018). Oleh karena itu, pemahaman tentang berbagai hal yang berkaitan dengan evaluasi hasil belajar para guru atau peserta pelatihan sangat perlu untuk ditingkatkan. Dengan demikian kompetensi profesional para guru dapat meningkat. Hasilnya kompetensi siswa pun akan terukur secara akurat sehingga para guru dapat memberikan tindakan yang tepat untuk meningkatkan kompetensi para siswa. 
Selanjutnya, berkaitan dengan pemahaman para guru atau peserta pelatihan tentang penyelenggaraan evaluasi secara online atau daring juga masih sangat rendah. Dari sejumlah peserta pelatihan hanya sebanyak $33,3 \%$ yang telah mengenal pelaksanaan evaluasi secara online atau daring. Hal ini tentu sangat memprihatinkan, terlebih-lebih di saat pandemik covid19 ini semua sistem pembelajaran harus dilangsungkan secara online atau daring. Oleh karena itu, pemahaman dan kemampuan para guru tentang sistem pembelajaran dan evaluasi secara online atau daring mutlak diperlukan sehingga pelaksanaan pembelajaran akan berlangsung secara efektif.

Eksplorasi awal lebih lanjut lagi adalah berkaitan dengan pemanfaatan salah satu media evaluasi secara online, yaitu Quizizz. Berdasarkan evaluasi awal dapat diketahui, bahwa seluruh guru atau peserta pelatihan $(0,0 \%)$ belum paham tentang penyelenggaraan evaluasi dengan menggunakan media Quizizz. Media online atau daring yang digunakan oleh para guru atau peserta pelatihan baru sebatas WhatsApp.

Selanjutnya, berdasarkan hasil eksplorasi tentang pemahaman dan kemampuan awal para peserta pelatihan tentang evaluasi dan pengembangan instrumen evaluasi secara daring, kami melangsungkan kegiatan pelatihan, yaitu dalam sesi elaborasi. Kegiatan elaborasi secara leksikal bermakna penggarapan. Artinya, berdasarkan temuan data atau informasi tentang tingkat pemahaman para peserta, selanjutnya akan dilakukan pemilihan metode serta tingkat kedalaman materi pelatihan yang tepat bagi para peserta kegiatan pelatihan.

Kegiatan elaborasi yang dilangsungkan dibagi menjadi tiga tahap, yaitu pemodelan, mengonstruksi secara berasama atau terbimbing, dan mengonstruksi secara mandiri. Pada tahap pemodelan, para peserta pelatihan diberikan penjelasan secara teoretis maupun contoh praktis penyusunan instrumen evaluasi hasil belajar dengan menggunakan media Quizizz. Pada tahap pemodelan juga berlangsung diskusi antara peserta dengan istruktur. Para peserta dapat mengajukan pertanyaan manakala ada berberapa hal yang belum dimengerti menganai apa yang sedang dijelaskan atau dicontohkan oleh instruktur. Pada tahap mengonstruksi secara terbimbing atau secara bersama, para peserta diberikan kesempatan untuk menyusun intrumen evaluasi hasil belajar dengan media Quizizz secara terbimbing serta dapat berdiskusi dengan teman sejawat. Selanjutnya, pada tahap mengonstruksi secara mandiri, para peserta diberikan kesempatan secara induvidu untuk menyusun instrumen evaluasi hasil belajar dengan menggunakan media Quizizz secara mandiri. Hal ini digunakan sebagai upaya untuk memastikan, bahwa setiap peserta pelatihan telah paham dan mampu dalam Menyusun intrumen evaluasi hasil belajar dengan menggunakan media Quizizz sebagaimana telah diajarkan atau diarahkan oleh instruktur pada tahap pemodelan dan memproduksi secara bersama-sama.

Secara mandiri para peserta mempraktikkan penggunaan media Quizizz baik sebagai guru dan sebagai siswa sebagaimana yang sudah dijelaskan oleh narasumber. Hal ini berlangsung selama 20 menit. Setelah itu, secara bergantian perwakilan mempresentasikan hasil ujicobanya tentang penggunaan media Quizizz. Melalui presentasi tersebut dapat diketahui, bahwa para peserta pelatihan umumnya sudah mampu menggunakan media Quizizz sebagai media evaluasi hasil belajar siswa. Hasil presentasi tersebut selanjutnya diulas serta diberikan penguatan 
mengenai komponen-komponen yang berkaitan dengan beberapa menu dan fitur tambahan yang mampu menyemangati siswa dalam mengerjakan latihan atau soal yang terdapat pada aplikasi Quizizz

\section{Hasil Pelatihan Penyusunan Instrumen Evaluasi Hasil Belajar dengan Menggunakan Media Quizizz}

Setelah kegiatan pelatihan secara webinar melalui google meet berlangsung, yang dilangsungkan pada tahap elaborasi yaitu berupa penjelasan dari narasumber mengenai cara penggunaan media aplikasi Quizizz, peserta pelatihan memiliki gambaran konkret mengenai cara penggunaan media tersebut. Selanjutnya, secara bersama dan dipandu oleh narasumber para peserta pelatihan menerapkan media Quizizz dalam menyusun instrumen evaluasi hasil belajar sesuai dengan mata pelajaran yang diampu. Secara bertahap para peserta pelatihan dipandu oleh narasumber menyusun instrumen evaluasi dengan menggunakan media Quizizz.

Melalui praktik pemanfaatan evaluasi dengan menggunakan media Quizizz para peserta merasa tertantang karena ada skor yang diperoleh dengan menjawab secara cepat dan tepat, dimana terdapat kecepatan akan ada skor sendiri dalam menjawab pertanyaan per soal. Selain itu akan ada persaingan dalam kelas karena, Quizizz langsung membuat ranking yang bersifat langsung antar peserta dalam kelas (Safitri \& Putra, 2019). Hal ini tentu sekaligus meringankan kerja guru untuk mengevaluasi hasil belajar siswa. Penggunaan media yang tepat seperti Quizizz akan membuat pembelajaran menjadi efektif.

Berdasarkan kegiatan pelatihan yang telah diaksanakan dapat diketahui, bahwa terdapat peningkatan yang signifikan mengenai pemahaman dan kemampuan para peserta pelatihan atau guru tentang penyusunan instrumen evaluasi hasil belajar dengan menggunakan media Quizizz. Peningkatan para peserta pelatihan secara kuantitatif dapat dilihat memalui Tabel 2 berikut.

Tabel 2. Rata-Rata Pemahaman Akhir Para Peserta Pelatihan tentang Evaluasi dan Pemanfaatan Media Online

\begin{tabular}{llll}
\hline $\begin{array}{l}\text { Pemahaman tentang } \\
\text { evaluasi }\end{array}$ & $\begin{array}{l}\text { Pemahaman tentang } \\
\text { media daring dalam } \\
\text { pelaksanaan evaluasi }\end{array}$ & $\begin{array}{l}\text { Pemahaman tentang } \\
\text { media Quizizz dalam } \\
\text { pelaksanaan evaluasi }\end{array}$ & Rata-rata \\
\hline $88,4 \%$ & $85,3 \%$ & $86 \%$ & $86,6 \%$ \\
\hline
\end{tabular}

Pemahaman para peserta pelatihan atau guru tentang prinsip-prinsip evaluasi yang semula hanya sebesar $44,4 \%$ menjadi $88,4 \%$. Hal tersebut menunjukkan, bahwa para peserta telah memahami dengan baik tentang prinsip-prinsip evaluasi. Pemahaman tersebut sangat penting karena menjadi ladasan yang kuat bagi guru untuk menyusun dan melangsungkan evaluasi. Dengan demkian, hasil serta tindak lanjut atas pelaksanaan evaluasi pun dapat dipertanggungjawabkan. Evaluasi program, dalam hal ini program pembelajaran hadir untuk memberikan masukan, kajian dan pertimbangan dalam menentukan apakah program pembelajaran layak untuk diteruskan atau dihentikan (Munthe, 2015).

Selanjutnya mengenai pemahaman para peserta pelatihan media online atau daring yang dapat digunakan dalam pelaksanaan evaluasi juga meningkat secara signifikan, yaitu sebesar 
$85,3 \%$. Semula, para guru hanya memahami media WhatsApp yang dapat digunakan untuk melangsungkan pembelajaran dan evaluasi secara online. Setelah mengikuti pelatihan, para guru memahami bahwa media online yang dapat digunakan untuk melangsungkan pembelajaran maupun evaluasi secara online sangat beragam. Para guru dapat menggunakan media Zoom, Google Meet, Google Form, dan juga media Quizizz.

Berikutnya, secara khusus tentang pemanfaatan media Quizizz dalam penyusunan dan pelaksaanan evaluasi hasil belajar juga telah meningkat secara signifikan, yaitu sebesar $86 \%$. Peningkatan tersebut tentu sangat berdampak positif terhadap kompetensi professional para guru. Para guru dapat menyusun instrumen evaluasi sekaligus melangsungkan evaluasi secara efektif karena di dalam media Quizizz guru dapat mendapat informasi beragam bahan yang digunakan untuk menyusun instrumen evaluasi. Di samping itu, penghitungan skor hasil evaluasi juga dapat diperoleh secara mudah. Bahkan para guru juga dapat mendapatkan informasi secara langsung mengenai tingkat kesulitan dari tiap-tiap instrumen evaluasi. Dengan demikian, para guru dapat dengan mudah menentukan tindak lanjut hasil evaluasi yang telah dilangsungkan dengan menggunakan media Quizizz tersebut.

Di samping melalui data kuantitatif di atas, kompetensi para peserta pelatihan dalam menyusun instrumen evaluasi hasil belajar dengan menggunakan media Quizizz juga dapat ditunjukkan melalui gambar berikut yang diambil pada saat proses pelatihan berlangsung secara virtual dengan menggunakan Google Meet.

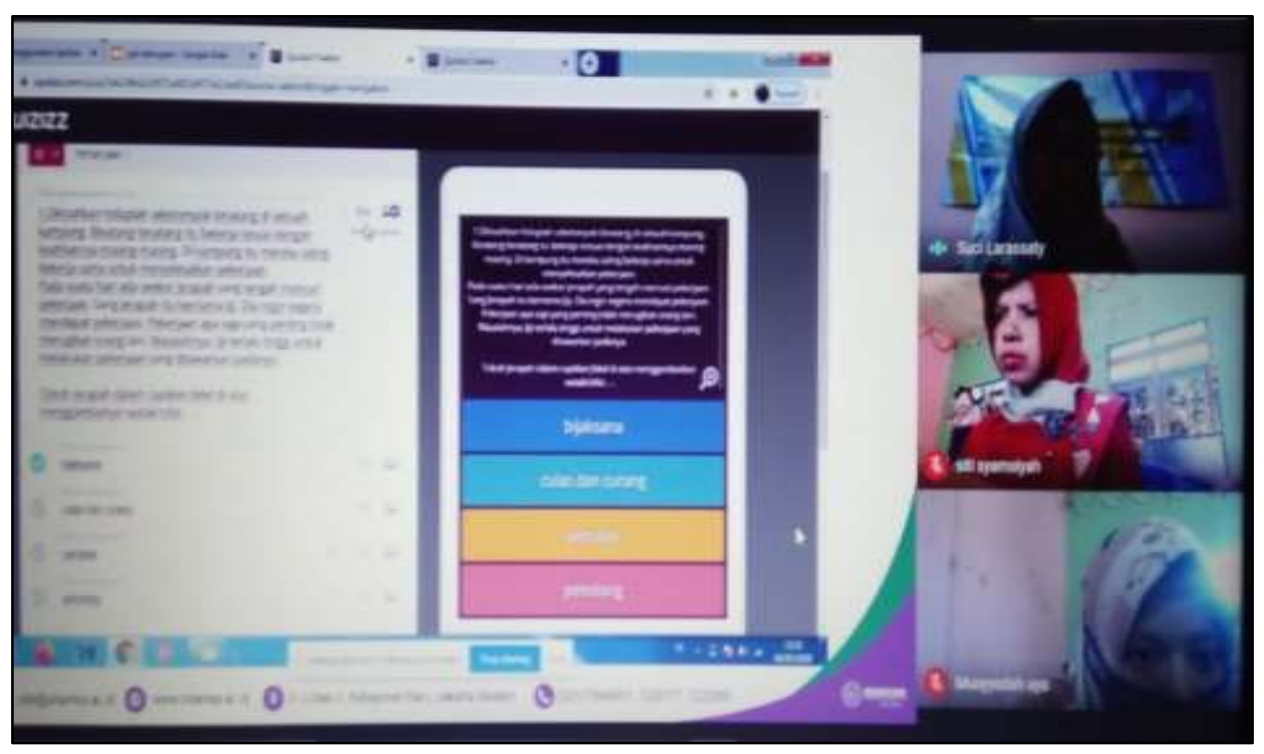

Gambar 1. Proses dan hasil pelatihan penyusunan instrumen evaluasi hasil belajar dengan media Quizizz

Berdasarkan gambar di atas dapat diperoleh informasi, bahwa para peserta pelatihan telah mampu menyusun instrumen evaluasi hasil belajar dengan menggunakan media Quizizz. Secara bertahap, para peserta telah mampu mengunduh, log in, dan mengoperasikan media Quizizz dengan baik. Para peserta juga sekaligus dapat bersimulasi menyusun dan melakukan evaluasi secara online atau daring dengan menggunakan media Quizizz. Menurut peserta media Quizizz sangat efektif dan menyenangkan. Yang tidak kalah pentingnya, reliabilitas dan validitas 
penyelenggaraan evaluasi hasil belajar dengan menggunakan Quizizz juga dapat dipertanggungjawabkan.

\section{Kesimpulan}

Berdasarkan pelaksanaan kegiatan pelatihan yang telah dilangsungkan dapat diketahui, bahwa pemahaman para peserta pelatihan atau guru tentang evaluasi telah meningkat. Ratarata pemahaman awal para peserta pelatihan tentang evaluasi, beberapa media online dalam penyelenggaraan evaluasi, dan pemanfaatan media Quizizz hanya sebesar 44,4\%. Setelah mengikuti kegiatan pelatihan yang dilangsungkan secara virtual melalui Google Meetmeningkat sangat signifikan, yaitu menjadi $86,6 \%$. Hal ini menunjukkan, bahwa kegiatan pelatihan yang diselenggarakan secara online bagi para peserta pelatihan berlangsung secara efektif.

Kegiatan pelatihan penyusunan instrumen evaluasi melalui media Quizizz yang dilangsungkan secara online (webinar) mampu meningkatkan kompetensi profesional para guru dalam menyusun dan melaksanakan evaluasi hasil belajar. Melalui media Quizizz, para guru dapat dengan mudah menyusun dan melangsungkan evaluasi secara online. Di samping itu, para guru juga mampu dengan cepat mengetahui tingkat keberhasilan siswa dalam mengikuti kegiatan belajar yang telah dilangsungkan. Dengan demikian, guru pun dapat lekas mengambil tindakan yang tepat dalam melangsungkan serta meningkatkan proses pembelajaran berikutnya. Berdasarkan efektivitas pelaksanaan pelatihan tersebut, pelatihan serupa di masa pendemi covid-19 ini perlu digalakkan.

\section{Referensi}

Cheng, K. H., \& Tsai, C. C. (2019). A case study of immersive virtual field trips in an elementary classroom: Students' learning experience and teacher-student interaction behaviors. Komputers and Education, 140, 103600. DOI: https://doi.org/10.1016/j.compedu.2019.103600

Crişan, A., \& Enache, R. (2013). Virtual Classrooms in Collaborative Projects and the Effectiveness of the Learning Process. Procedia - Social and Behavioral Sciences, 76, 226-232. DOI: https://doi.org/10.1016/j.sbspro.2013.04.103

Daly, D., Rasmussen, A. V., \& Dalsgaard, A. (2019). Learning about midwifery in another country from a distance: Evaluation of a virtual classroom learning session. Nurse Education Today, 75, 47-52. DOI: https://doi.org/10.1016/j.nedt.2019.01.007

Kultawanich, K., Koraneekij, P., \& Na-Songkhla, J. (2015). A Proposed Model of Connectivism Learning Using Cloud-based Virtual Classroom to Enhance Information Literacy and Information Literacy Self-efficacy for Undergraduate Students. Procedia - Social and Behavioral Sciences, 191, 87-92. DOI: https://doi.org/10.1016/j.sbspro.2015.04.394

Li, C., Wei, X., Zhao, Y., \& Geng, X. (2020). An effective maximum entropy exploration approach for deceptive game in reinforcement learning. Neurocomputing, 403, 98-108. DOI: https://doi.org/10.1016/j.neucom.2020.04.068

Mastuti, E. (2016). Pemanfaatan Teknologi Dalam Menyusun Evaluasi Hasil Belajar : Kelebihan Dan Kelemahan " Tes Online " Untuk Mengukur Hasil Belajar Mahasiswa Jurnal Penelitian Psikologi, O701), 10-19.

Mei, S.Y., Ju, S.Y., \& Adam, Z. (2019). Implementing Quizizz as Game Based Learning in the Arabic Classroom. European Journal of Social Science Education and Research, 5(1), 194-198. DOI: https://doi.org/10.2478/ejser-2018-0022

Morice, A., Jablon, E., Delevaque, C., Hossein Khonsari, R., Picard, A., \& Kadlub, N. (2020). Virtual versus traditional classroom on facial traumatology learning: Evaluation of medical student's 
knowledge acquisition and satisfaction. Journal of Stomatology, Oral and Maxillofacial Surgery. 809, 1-14. DOI: https://doi.org/10.1016/j.jormas.2020.03.001

Munthe, A. P. (2015). Pentingnya Evaluasi Program di Institusi Pendidikan: Sebuah Pengantar, Pengertian, Tujuan dan Manfaat. Scholaria: Jurnal Pendidikan Dan Kebudayaan, 5(2), 1-14.

Peraturan Pemerintah Republik Indonesia Nomor 21 Tahun 2020 Tentang Pembatasan Sosial Berskala Besar Dalam Rangka Percepatan Penanganan Corona Wrus Disease 2019 (COVID-I9)

Purba, L. S. L. (2019). Peningkatan Konsentrasi Belajar Mahasiswa Melalui Pemanfaatan Evaluasi Pembelajaran Quizizz Pada Mata Kuliah Kimia Fisika I. Jurnal Dinamika Pendidikan, 12(1), 29. DOI: https://doi.org/10.33541/jdp.v12i1.1028

Purnomo, E. (2005). Evaluasi Hasil Belajar Dalam Implementasi Kurikulum Berbasis Kompetensi Di Sekolah Menengah Kejuruan. 2, 259-272. https://doi.org/10.21831/cp.v0i2.372

Raes, A., Vanneste, P., Pieters, M., Windey, I., Van Den Noortgate, W., \& Depaepe, F. (2020). Learning and instruction in the hybrid virtual classroom: An investigation of students' engagement and the effect of quizzes. Komputers and Education, 143, 1-16. DOI: https://doi.org/10.1016/j.compedu.2019.103682

Rajab, M. (2020). No Title. Diakses di https://News.Detik.Com/Kolom/d-4960905/Evaluasi-DanOptimalisasi-Pembelajaran-Daring.

Safi'i, I. (2018). Nilai-nilai Pendidikan Karakter dalam Alat Evaluasi Bahasa Indonesia. Jurnal Pendidikan Karekter Pendidikan, 8(1), 74-83.

Safi'i, I., \& Amar, F. (2019). Pelatihan Penyusunan Instrumen Evaluasi Berstandar HOTS bagi GuruGuru SD di Wilayah Banyudono. Abdimas Dewantara, 2(2), 149-157.

Safitri, D., \& Putra, Z. F. F. (2019). Pemberdayan Kelompok Guru Dalam Membuat Media Pembelajaran Quizizz. Prosiding Pengabdian, 1(1), 1-6.

Soffer, T., Kahan, T., \& Livne, E. (2017). E-assessment of online academic courses via students' activities and perceptions. Studies in Educational Evaluation, 54, 83-93. DOI: https://doi.org/10.1016/j.stueduc.2016.10.001 